\title{
Land Reform Policies, The Sources of Violent Conflict and Implications for Deforestation in the Brazilian Amazon
}

\author{
Lee J. Alston \\ University of Illinois \\ NBER \\ Gary D. Libecap \\ University of Arizona \\ NBER \\ Bernardo Mueller \\ Universidade de Brasilia \\ July 1999
}

\begin{abstract}
In this paper we examine land reform policies and their implications for violent conflict over land and resource use in the Brazilian Amazon. We identify the protagonists (land owners and squatters), derive their incentives to use violence, and show the role of legal inconsistencies as a basis for conflict. Although civil law guarantees title for land owners, the Brazilian Constitution adds a beneficial use criterion as a condition for title enforcement. This provision is part of a land reform or redistribution effort and it provides authorization for transfers to squatters. We describe the government agency involved in land reform, INCRA, and show that its intervention critically affects the actions of both squatters and land owners. Further, we point out the resource use effects of land reform policies and associated insecure property rights to land. Forested lands on large farms do not meet the constitutional beneficial use criterion and hence, are vulnerable to invasion by squatters and redistribution by INCRA. In the contest for control, land owners and squatters have incentives to deforest more rapidly and extensively prior to a conflict than agricultural production alone would warrant in order to demonstrate their respective land use. In analyzing the determinants of violent conflict, an analytical framework is provided to generate hypotheses for testing. Using data from the Brazilian census and the Pastoral Land Commission for the state of Para we examine the characteristics of regions where violent conflict predominates. Our empirical results indicate that a greater policy emphasis on land reform in Brazil through expropriation to reduce violent conflict, may have the unanticipated effect of increasing violent competition and wasteful resource use. The results of the paper are suggestive not only for Brazil, but for elsewhere in Latin America where there is tension between the goals of secure property rights and wealth redistribution.
\end{abstract}

\footnotetext{
We acknowledge financial assistance by NSF grant SBR 9512107 and research support from the International Center for Economic Research, ICER, Turin, Italy. We are grateful to the Pastoral Land Commission for access to data on land conflicts. We thank the referees and editors for helpful comments and the research assistance of Jeffrey Fuller and Tom Nonnenmacher. Other insights were provided at seminars at the Universidade de Brasilia, University of California-Santa Barbara, FGV in Rio de Janeiro, University of Illinois, the Max Plank Institute in Jena Germany, Queens University, Universidade do Rio Grande do Sul, University of Toronto, Vanderbilt University, the PARADI Conference, Montreal, Conference on Social Conflict and Economic Performance, University of California, Irvine, 1999, and the Econometrics Society, Summer Meetings, June 1996.
} 


\section{Introduction}

In this paper we examine violent conflict and resource use implications when property rights to land and land reform (redistribution) clash. ' In Brazil, there is inconsistency between civil law that supports the title held by land owners and constitutional law that supports the right of squatters to claim land that is not in "beneficial use." This constitutional provision is part of land reform in a country characterized by highly skewed land ownership and wealth. ${ }^{2}$ Given the vagueness of the use criteria and uncertainty as to when a land owner's claim or a squatter's counter claim is enforced, the potential for violence is established. Further, to demonstrate productive land use and firm their respective, competing claims, both land owners and squatters have incentives to deforest more rapidly prior to a conflict than agricultural production alone would warrant. These effects appear to be extensive and they undermine efforts to maintain the Amazon rain forest.

Violent conflict over land, however, is not a uniform characteristic of the Amazon frontier; it appears to occur systematically in certain places. This paper examines the underlying factors that cause violence to take place. Consider the eastern Amazon state of Para, which is the second largest state in Brazil and which has the largest number of land disputes in the region. ${ }^{3}$

Of the 105 municipios (counties) in Para, 54 municipios had recorded at least one conflict between 1987 and $1994 .{ }^{4}$ During that time, there were 350 conflicts in the state, and ten

\footnotetext{
' On April 17, 1996, there was violent confrontation between squatters and police in the municipio (county) of Curianopolis in the Amazonian state of Para in which 20 or more people were killed. Squatters invaded large farms and claimed unused land. At the behest of farm owners, police were called to evict the squatters. Squatters, however, resisted eviction and blocked a major highway, PA-150. Fatalities occurred as the police attempted to clear the road. Conflicts such as this one have drawn international attention to Brazil. See The New York Times. April 21, 1996, p. 8; for a related discussion, see Mary Anastasia O'Grady, "Muddled Policies Spark Brazilian Land Wars," Wall Street Journal. October 20, 1995, p. A15.

${ }^{2}$ In 1985, the Gini coefficient for land ownership in Brazil was 0.854. See C. Mueller (1987).

3 IDESP. Para Agrario. No. 1-7.

4 Data on conflicts between 1987 and 1994 are from the Pastoral Land Commission (CPT) Annual Reports. The CPT collects data on land conflicts, and we have researched their files in Goiania. Earlier data on conflicts and number of fatalities is available in IDESP, Para Agrario. No. 1, 1986, p. 51 and MIRAD, Violencia no Campo. 1985.
} 
municipios had more than ten conflicts each. From 1983 to 1994 at least 311 people were killed in land disputes in Para, but violence was concentrated in just nine municipios that accounted for 238 or 77 percent of all deaths. ${ }^{5}$ Seven of these municipios, with 196 fatalities, were in southeast Para near the border of the state of Tocantins. ${ }^{6}$ In many other areas, there were no recorded confrontations. Accordingly, relevant empirical questions for our study are: what are the policy and legal conditions that lead to violent land disputes, what are the characteristics of those areas that have conflicts relative to those that do not, and what are the resource use implications?

The study identifies the inconsistencies in the nature and administration of Brazilian land, law and land reform that lead to conflicts. It isolates the characteristics of the municipios most likely to have them, and concludes that the current process of land reform may perversely encourage even more violence, the opposite outcome from what is intended. Additionally, the study shows how land reform policies and insecure property rights to land encourage more rapid deforestation than likely would otherwise occur.

\section{Accelerated Deforestation as an Outcome of Land Reform in the Amazon.}

In the Amazon, clearing forest on a plot of land is an investment. It is a difficult and costly activity and will be engaged in by both small and large land owners based on economic calculations. Even with perfectly defined property rights the result of this calculus usually will be positive levels of clearing each year in order to capture the economic potential of the land. In the Brazilian Amazon, however, property rights are rarely well defined, and claimants have to dissipate part of their rents as a consequence, clearing more than justified by direct production

\footnotetext{
' These municipios and cumulative number of deaths are Conceicao do Araguaia (12), Maraba (51), Paragominas (17), Rio Maria (18), Santana do Araguaia (20), Sao Felix do Xingu (11), Sao Joao do Araguaia (10), Viseu (25), and Xinguara (74).

' Conceicao do Araguaia, Maraba, Rio Maria, Santana do Araguaia, Sao Felix do Xingu, Sao Joao do Araguaia, and Xinguara.
} 
possibilities to better establish their claims. The threat of invasion and/or expropriation has led land owners to prematurely replace forest with pasture. This activity not only strengthens their property rights and thus reduces the probability of an invasion by squatters and an expropriation, but even if an expropriation occurs, the "improvement" from clearing will be fully compensated by the government in cash, as opposed to the land itself which is compensated in titles of agrarian debt. Further, in dividing a disputed farm between land owners and squatters, each may be given a multiple of the land cleared (put into productive use). ${ }^{8}$

It is difficult to measure the separate deforestation effects of production possibilities, il1defined property rights in general, and the land reform program in particular. Regions of the Amazon are susceptible to these effects in differing degrees depending on their characteristics. Nevertheless, the greater are land owner expectations that their region will be included in the land reform program, the greater are their incentives to clear to preempt squatter trespass and subsequent conflict. These incentives are well recognized by policy makers, government agencies, non-government organizations (NGOs), and the media. For example, a report by the federal environmental agency, IB A M A, on prevention and control of forest fires in the Amazon pointed to land reform as one of the main motives for deforestation by land owners: "the process of invasion and occupation of large rural properties leads land owners to clear much of their remaining areas of primary forest due to the fear of being identified as holders of unproductive areas."

Indeed, land owners in the Amazon face different incentives from the environmental policies of I B A M A and the land reform policies of the federal land reform agency, IN CRA (the

\footnotetext{
' In the 1970's and 1980's land owners also were encouraged by subsidized credit and fiscal incentives to clear their farms beyond what production would warrant. During the 1990's these incentives for deforestation have been drastically reduced but in many areas they have been replaced by those from the land reform program.

${ }^{s}$ See Alston, Libecap, and Mueller (1999, Chapter 3) and Heath and Binswanger (1996).

' IB A MA, 1998, Programa deprevencdo e Controle de Queimadas e Incendios Florestais no Arco de Desjlorestamento da
} 
National Institute for Colonization and Agrarian Reform). Whereas IB A M A administers a law that requires properties in the Amazon to retain 80 percent of their area in forest, INCRA will often consider a property that follows this rule as unproductive and thus susceptible to expropriation. ${ }^{10}$ Formally, the resolution dictates that land owners register the forested part of the property at IBAMA as a natural reserve, thus exempting it from punitive taxes and expropriation. In practice, however, this action involves a costly and bureaucratic procedure, including hiring a certified agronomer to prepare a forest management plan. Additionally, once the reserve is registered, the land owner losses the option to clear that area in the future, whereas an unregistered forest can be cleared at a lower risk of detection by IB A MA. Accordingly, few landowners choose to register with I B A M A. Our surveys of land owners in the south of Para indicate that when forced to select which rules to follow and which to break, land owners more often will clear and risk a fine from IB A M A than to risk losing their farm through invasion and expropriation.

Squatters also have incentives to deforest under the current land reform regime. A 1997 report of a special committee of the Brazilian House of Representatives on the causes of Amazon deforestation reported that the land reform program was a major contributor. The committee argued that from 1964 to 1997 land reform programs were responsible for 30 percent of documented deforestation, covering approximately 15 million hectares. ${ }^{12}$ Other critics charge that the existing land reform program is encouraging an even faster rate of deforestation at 1.85

\footnotetext{
Amazonia, Brasilia, MMA/IB AMA.

${ }^{10}$ Policy makers often try to argue that environmental policies and social policies for the Amazon need not be mutually exclusive, however, in practice policies that reconcile these two goals are rare exceptions.

"In surveys we conducted in conflict-prone areas of southern Para land owners admitted to clearing more of their farms because INCRA was expected in the municipio in response to requests by several squatter groups. The owners realized that the more land they had cleared, the more they would be allowed to keep or be compensated for if targeted by INCRA. Of the 42 farmers surveyed only one had implemented a forest management program with IBAMA.

${ }^{12}$ Goncalves, M.A. (1998). The Committee was headed by a deputy from the Labor Party (PT), which holds land reform as one of its main banners, and its foremost goal was to investigate the activity of Asian logging companies in the Amazon. The Committee's report was sharply criticized by the Minister of Land Reform who stated that the contribution of the land reform
} 
million hectares per year. ${ }^{13}$ According to INCRA, there are currently 298 land reform projects in Para, with 90,023 families on over 5 million hectares of land. Considering that practically all projects were created from farms deemed not productive and largely covered in forest, conversion to small farms will bring deforestation. Squatters who receive land as part of an expropriation are given credit and other types of assistance so that they can start planting and become self-sufficient. Indeed, INCRA's performance is measured in terms of how many families it is able to settle on expropriated farms. Hence, success by INCRA almost inevitably also implies high levels of deforestation. Squatters must clear in order to plant for their subsistence, and the sale of valuable lumber helps to finance their efforts. ${ }^{14}$ Clearing also creates a fait accompli that signals their intention to occupy the land. A land owner who has forested ("unproductive") land and who encounters well-entrenched squatters may choose to avoid conflict and effectively cede the land to the new claimants. As in the case of the land owner, clearing is considered by INCRA to be an improvement, and even if squatters are ultimately evicted, they have a right to be compensated for improvements.

Most deforestation occurs through burning. Besides the intentional fires used to clear land for farming, there is also considerable environmental damage that comes from accidental fires. A recent study by IP AM (Amazon Environmental Research Institute) found that in 19941995, 48 percent of the area burned in the Amazon was due to accidental fires - 12 percent in forested areas and 36 percent in pasture and crop lands. ${ }^{15}$ Although this study tactfully avoided saying whether large or small landholders were responsible for most of the burning, the president of I B A M A allocates deforestation across small, medium and large land owners at 40 percent, 34

program to the deforestation was much smaller and he blamed cattle ranchers, logging companies, and gold-miners. ${ }^{13}$ Furtado,B. (1997).

${ }^{14}$ In most cases, by the time the squatters invade an area most valuable lumber will have already been extracted by the land owner or by loggers.

${ }^{15}$ I P A M (1997). The study indicates that area burned varied from 6 hectares/year on some small properties to 5,000 
percent and 26 percent. ${ }^{16}$ Whatever the actual sources of clearing, settling large numbers of families in the Amazon through the land reform program accelerates deforestation in the region.

\section{The Institutional Environment for Land Reform and Violence.}

In addition to accelerated deforestation, land reform policies appear to encourage violent competition over land. To understand the sources of conflict, it is important to review the institutional environment in which settlement takes place and identify the parties involved.

Under Brazilian law, government land \{terra devoluta) is open for private claiming and settlement. Although the Amazon frontier long has attracted settlers and adventurers from other parts of Brazil, the region remained relatively unexploited until the early 1970s. By that time new road construction, such as the TransAmazon, Belem-Brasilia, and Cuiaba-Santarem highways, had linked the area to the rest of Brazil and reduced transportation costs. Further, formal colonization efforts (colonizagao oficial) were instituted by the Brazilian government to accelerate the settlement of the Amazon and to address political pressures for land reform. With migration to the Amazon frontier the population of Para grew from 2.2 million to 4.3 million between 1970 and 1985, and the amount of land in farms doubled."

In this migration, both large and small holders claimed frontier land. Large holders obtained property through the purchase or granting of state and federal lands for development. ${ }^{18}$ Some private tracts were very large, 24,000 hectares or more, but most were smaller, around 5,000 hectares. ${ }^{19}$ These large holdings were referred to as latifundia, and many were not put into productive use initially because of high transportation costs. Titleholders waited, often until

hectares/year on larger properties in the south of Para.

${ }^{16}$ Gondim, A.,1997, Guerra deNumeros, Folha de Sao Paulo. Dez. 27, pg. 19.

${ }^{17}$ TRGR. Anuario Estatistico do Brasil H990. p. 183; 1991, pp. 180-183).

${ }^{18}$ For discussion, see Ianni (1979) and Mahar (1989, p. 15).

${ }^{19}$ Monteiro (1980); Schmink and Wood (1992, p. 196). The 1988 Brazilian Constitution lowered the size limit for sales without Senate approval to 2,500 hectares. A survey of 69 contested properties that we conducted in December 1996 in Para involved large farms ranged in size from 150 hectares to 411,000 hectares with a mean of 15,112 hectares. 
1975 or later, until increased investment by the federal government in roads or the inauguration of other subsidies raised the value of the lands sufficiently to justify rainforest clearing and landspecific investment. ${ }^{20}$

Small holders typically claimed 150 hectares or less. Some small farmers obtained government land through formal colonization projects administered by a federal government agency, INCRA that was created in 1971. ${ }^{21}$ Most small-holder settlement, however, occurred spontaneously outside colonization areas along new road construction. ${ }^{22}$ These small claimants secured land through squatting on either government or importantly, "unused" private land.

Under Brazilian law, squatters (posseiros) have the right (direito de posse) to live on unclaimed government land and to put it into private use. If they develop the land "effectively" for at least one year and one day, squatters can receive a usufruct right to 100 hectares and after five years, full title through continued occupancy and beneficial use (cultura efetiva e morada habitual). One of the functions of INCRA, is surveying, documenting, and ultimately titling squatter claims to government lands. To begin the titling process, squatters organize to lobby local INCRA offices to recognize their holdings. Agency response depends upon budget and staffing so that several efforts by squatter groups may be necessary before action is taken. ${ }^{23}$

Title is desired by both large and small land claimants. The rights of title holders come from statutory law (Civil Code). In principle, the legal rights from having a title in Brazil are similar to the legal rights to title under common law in the United States - subject to paying taxes, title holders have the right "to use, enjoy, and dispose of the goods, and to receive them back

\footnotetext{
20 For example, Gasques and Yokomizo (1986) report that of 29 subsidized cattle ranches with an average size of 16,334 hectares, 14 sold no cattle at all, and only two reached more than 50 percent of their target production between 1974 and 1985.

${ }^{21}$ A similar state agency, ITERPA, was established by Para in 1975 to coordinate settlement and to process title applications on state government lands.

${ }^{22}$ Sawyer (1984, p. 189); Pinto (1980, p. 187).

${ }^{23}$ Pinto (1980, p. 42).
} 
from those who unjustly possess them." ${ }^{24}$

Despite these legal provisions, various Brazilian Constitutions have both abrogated the rights of title holders and given squatters preferential privileges as part of land reform. Not only can squatters occupy and claim government land, but they can occupy up to 50 hectares of vacant private land. If they develop and occupy their claims for five consecutive years without opposition from the owner, squatters can obtain title through adverse possession. If the owner protests this occupation and has the squatters evicted, squatters have the right to be compensated by the land owner for any improvements they have made.

For example, consider the most recent Constitution of $1988:^{25}$

1. Article 189 - It is up to the Union to expropriate for social interest (emphasis added), for the purpose of agrarian reform, the rural establishment which is not fulfilling its social function....

2. Article 191 - The social function is fulfilled.... the following requirements:

a) adequate and rational use;

b) adequate use of the natural resources available and preservation of the environment.

c) observance of the dispositions which regulate labor relations.

d) exploration which favors the well-being of the proprietors and workers. 3. Article 196 - One who, not being the proprietor of a rural or urban establishment, possesses as his/her own for five uninterrupted years, without opposition, an area not greater than fifty hectares, making the land productive through his/her labor, or that of his/her family, having in the land their habitation, will acquire the property.

The difficulty these constitutional land redistribution provisions bring for the security of title is obvious. Essentially, they authorize the invasion of private land if it is not placed into "beneficial" use, however defined. Typically, uncleared forest land in the Amazon is prima facie evidence of a lack of beneficial ("adequate and rational") use, but any definition will be arbitrary and invite disputes. As a squatter in the municipio of Conceicao do Araguaina in Para stated:

\footnotetext{
${ }^{24}$ Article 524 of the Civil Code translated from Fachin (1991). See Alston, Libecap, and Schneider (1996) for discussion and analysis of the contribution of title to land value and investment.

ss The Constitution of 1946 and the 1964 Federal Law 4504 provided similar privileges for squatters.
} 
"Here the best title is the biggest ax." 26

The pressure for land reform in Brazil comes from a history since colonial times of government grants of large tracts of frontier land to influential parties and an associated extremely skewed distribution of land and wealth. Hence, very large (and often idle) holdings have co-existed with masses of landless peasants. This situation has created political pressures for land redistribution over time that have fluctuated with changes in political administrations and macro economic conditions in Brazil. ${ }^{27}$ The antagonists in land reform are large land owners and squatters. ${ }^{28} \mathrm{Th}$ e opportunities for squatting arise because many large private holdings are remote and of low value, and hence, have not been developed. Nevertheless, because squatters have comparatively lower opportunity costs, they find these lands attractive for settlement and production, even when the large title holder does not. ${ }^{29}$ So long as land values remain low, title holders have little incentive to monitor invasion and evict squatters. Further in heavily forested areas, monitoring costs are so high that the owner may not observe infringement by squatters.

According to Barata (1995) there has been an annual average of 59 fatalities in land conflicts between 1981 and 1989 in Para. ${ }^{30}$ Despite the potential for violent conflict between title holders and squatters, such disputes are not ubiquitous. Possible explanations include: 1) some titled land is put to productive use and hence not subject to squatting; 2) other titled land is not worth enough for landowners to monitor whether squatters are present; and 3) in certain

${ }^{26}$ Pinto (1980, p. 5).

27 For discussion of the history of land policy and land reform, see Alston, Libecap, and Mueller (1999, Chapters 2 and 3), Mueller, Alston, Libecap, and Schneider (1994), and Pendle (1983).

* Competition for land between these two groups accounts for the vast majority of land reform conflicts in Brazil. Conflicts between indigenous inhabitants on the one hand and squatters, ranchers, miners, local and state governments exist in Brazil, but they are much smaller in number and are quite separate from the process we are examining. They tend to be localized to specific Indian reserves and are more the jurisdiction of the Federal Indian Agency, FUNAI, than of INCRA. Most reserves are still remote and not included in land grants or other large private holdings nor involved in squatter infringements at this time. The most common problem is trespass on reserves by garimpeiros (small miners). Description of conflicts involving Indian reserves as well as other related data can be found in http://www.nativeweb.org/abayayala/cultures/brazil/cimi/.

29 For discussion of the characteristics of squatters, see Alston, Libecap, and Schneider (1995).

* Conflict and fatalities data vary by source, which are not always comparable. Our data presented at the beginning of the paper, include only conflicts strictly over land. Barata's (1995) data include a broader definition of conflicts. 
instances private negotiations are successful in avoiding conflicts, whereby title holders pay for improvements if squatters leave. Violent conflicts over land appear to be most probable where there are large holdings, where INCRA is likely to intervene on the squatters' behalf, and where rising land values change the incentives of the title holder to develop the land and of the squatters to resist eviction.

In land disputes between large title holders and squatters, the courts and the federal land agency, INCRA, play important roles. Brazilian judges treat a squatter invasion of a farm as they would any other taking of private property as interpreted in the Civil Code. ${ }^{31}$ Hence, courts can lower the land owner's costs of retaining possession of the land by adding state enforcement of property rights.

Following an invasion, land owners can appeal to the courts to issue a reintegragao de posse (reintegration of possession) which states that private property was taken from its rightful owner and should be returned immediately. If the court agrees, the document authorizes use of the police to evict squatters. In most cases land owners will first try to evict the squatters by their own means before appealing to the courts because the cost of obtaining a reintegragao de posse is high, around US $\$ 5,000$ in the state of Para in $1996 . .^{32}$ Additionally the courts can influence the costs to squatters and land owners in a land conflict through assessment of criminal charges against either party. Finally, courts can lower a land owner's costs of maintaining property rights by judging the legality of any action taken by INCRA to expropriate the farm for the squatters. Through an appeal to the courts, a land owner can challenge an expropriation decision on productivity grounds or question the value of compensation offered for his

\footnotetext{
"In Brazil judges are chosen based on a public examination open to all suitably qualified citizens. For discussion of the courts' role in land conflicts, see Fachin (1991).

sze estimate of the cost of obtaining a reintegracao de posse came from our field survey in 1996 in Para.
} 
expropriated land.

When squatters invade a property, they seek to have it expropriated from the owner and redistributed among the group. By law, INCRA has the authority to expropriate \{desapropriaqao) private land that is not fulfilling its social function and to use the property for land reform. Between 1985 and 1991, 30 percent of the land in government settlement projects in Para came from previous expropriations of private holdings. ${ }^{34}$

The expropriation process involves several steps. The first is selection of the area to be expropriated (selecao), followed by field inspection, survey, and valuation of the land and improvements (vistoria de campo). INCRA performs official appraisals (pericias) and submits the proposed expropriation to the court (ajuizamento) to obtain authorization for title transfer to the agency for subsequent distribution to squatters (imissao de posse).

Valuation of the land and improvements is based on price data held by banks, registered at cartorios, or known to rural extension officers and real estate brokers. The judge handling the case determines the final value, but land owners historically have received less than the market value of their land in an expropriation. ${ }^{35}$ If INCRA obtains court approval, it will pay for the land with Agrarian Debt Bonds, TD A, (titulos de divida agraria) and compensate for improvements with cash payments. The final decree of expropriation is issued by the central INCRA office and the President of Brazil.

\footnotetext{
s In 1997 INCRA owed approximately US\$ 1 billion dollars to 212 farmers who contested the levels of compensation proposed by INCRA. The payment due from INCRA rapidly grows as the cases move slowly through the federal courts system. Besides re-evaluating the price of the expropriated farm, the law demands that INCRA pay interest of 12 percent per year to account for the land owner's lost profits from not being able to use the (unproductive!) farm while the case is being settled. Also the law requires special compensation for any forest cover in the farm. As noted below, a Presidential Decree has since eliminated many of these legal distortions. Gondim, A., 1997, INCRA deve R\$ 1 bilhao em indenizacoes. Folha de Sao Paulo: 23.

* This figure is based on data collected from INCRA on 38 settlement projects in Para between 1985 and 1991 where it was possible to catagorize land into expropriations, purchased, and government land.

${ }^{35}$ According to law, compensation is to be "just." Compensation, however, is in titles of agrarian debt as described in the text. Until recently, such debt instruments (TDA's) were highly discounted. Land owners could challenge the value in the courts. Recently, the TDA's have risen in value. Some times landowners are able to secure compensation above the market price of the land, either through corruption involving INCRA officials or through the court. Such cases are, however, exceptions.
} 
It is possible, of course, that some land owners might prefer invasion and expropriation. In recent years holding land has become less attractive due to a series of factors such as the end of rural credit and fiscal incentives, economic stabilization, increased imports, and land reform. As a consequence, the price of land has fallen sharply and in some areas the best deal for a land owner wishing to sell his property would be expropriation by INCRA. In order to convince INCRA to actually expropriate a property the land owner could instigate an invasion with a group of squatters. The land owner could also scheme with local INCRA officials or use the courts to set the compensation for expropriated land above its market value.

Such actions, however, appear to be very isolated events. Occasionally the press exposes an expropriation where the land owner received compensation that exceeded the market price of the land and where collaboration was found between the property owner and the local INCRA staff. ${ }^{36}$ Press exposure embarrasses politicians and INCRA officials. In June 1997 the government passed a Presidential Decree to make such fraud more difficult. The decree established a precise methodology for price determination and raised the penalty for technical staff found to have inflated land values. Despite the attention that such cases receive, most rural conflicts do not involve fraudulent expropriation. INCRA has a limited budget and cannot accomplish its land reform targets, which it must constantly account, if it over compensates in land purchases.

In most cases, then, the expropriation process is complex, subject to dispute, and can take a long time. Indeed, expropriations can be extended several years if the land owner appeals to the courts, contesting the suggested compensation for the land and improvements or challenging the claim that the land was unproductive. Given the opposition of land owners, squatters are

\footnotetext{
${ }^{36}$ In 1997, for example, in Ourilandia, a municipio in Para, a farmer bought at a discount a farm that was already invaded. His intention was to have it expropriated by INCRA at a price above that which he had paid. Folha de Sao Paulo, 1997, "Fazenda foi
} 
careful to choose farms that can be expropriated, and thus ensure a higher probability that INCRA will intervene. ${ }^{37}$

Selection of the land to be expropriated is based on the organized lobby efforts of squatters and their rural workers' unions, such as the Movement of Landless Workers (MST). The MS T has grown rapidly as an effective squatter organization since its founding in 1984. It understands the formal, as well as the implicit, rules of the game, involving squatters, land owners, INCRA, the federal government, the courts, and public opinion. With this understanding, MS T develops a strategy for identifying a farm, invading it, and, most importantly, transforming the invasion into an expropriation by INCRA.

The constitutional rules that authorize expropriation for land reform are not necessarily the cause of violent rural conflicts, because they simply give incentives for squatters to invade private farms. If the owners believed that once their land was invaded they would lose their claim to it, then there would be no point in trying to evict the squatters. Effectively, they would walk away from any potential conflict with squatters. In practice, land owners are able to go to the courts under the Civil Code and request a warrant for the police to evict the squatters. If the owner has title, he will almost always be granted such a warrant, regardless of the extent of beneficial use. Although the courts are aware of the constitutional requirement that land be used productively, they are not charged with land reform. Land reform, however, is the specific mandate of INCRA. INCRA can expropriate farms even if the courts have ordered eviction. Similarly, if squatters believed that they would be evicted and that there would be no expropriation, then there would be no point in invading the farm. Under this circumstance,

Comprada apos a Invasao." Sao Paulo, Marco 29, pg.12.

${ }^{37}$ New legislation under consideration seeks to speed the process of transferring title from the owner to INCRA.

${ }^{3}$ s Until approximately 1985 INCRA relied less on expropriation and more on colonization projects on government land to address land reform pressures. At that time, then, there was less incentive for squatters to invade private farms because expropriation was less likely. 
they too would avoid potential conflict with owners. Uncertainty as to whether or not INCRA will intervene on behalf of squatters provides the necessary condition for violent conflict to occur. $^{39}$

INCRA, however, is faced with an allocation problem. Because the agency has limited budgets and staffing, it cannot respond to all squatter requests. Hence, squatters on a particular farm must find a means of attracting INCRA's intervention on their behalf. We argue that land conflicts can serve that purpose. Violent conflict attracts national and international media attention and embarrasses federal politicians, particularly the President. In Brazil the President is responsible for land reform..$^{40}$ There is an influential urban constituency in Brazil that supports land reform, and publicized incidents of violence and deaths result in criticism of the government. The President, in turn, pressures INCRA to resolve the disputes. For example, an article in the February 5, 1997, Veja, the largest weekly magazine in Brazil, linked a sharp drop in President Fernando Henrique Cardoso's approval ratings to the April 1996 land conflict in Para in which 19 squatters were killed. Following this conflict Cardoso created a new Ministry of Land Reform and placed INCRA within this ministry. ${ }^{41}$ The President can punish the agency if it appears not to be effective by cutting its budget or removing its director. This practice is frequent; between 1990 to 1996 there have been 19 INCRA heads.

Accordingly, in land disputes land owners seek to evict squatters before they can attract INCRA's intervention. Squatters resist eviction and attempt to have the farm expropriated by

\footnotetext{
3* For discussion of cases where conflicts are avoided in other contexts, see Priest and Klein (1975).

* In Brazil land reform has been a major political issue since the early 1960's and every government since then has had a specific land reform program. Since its creation in 1971 INCRA has had the task of implementing each government's program. During the 1970's and early 1980's the main instrument for reform was colonization, the settling of landless peasants on unused government land, mainly in the Amazon. This method, however, proved to be too slow and ineffective in attending the large number of peasants without land. Furthermore, public land tended to be remote and with little infrastructure and settlers preferred private unused lands that were closer to developed markets. As a consequence, INCRA turned to expropriations during the second half of the 1980s. Since 1985 all land reform programs in Brazil have been based on the idea of settling landless peasants on land obtained through expropriation.

" Rochaand Filho(1997).
} 
INCRA. It is during evictions that most violent conflicts occur.

\section{A Framework for Analyzing Violent Land Conflict in Land Reform.}

The institutional environment shapes the incentives of squatters and land owners in their decisions as to whether or how to confront one another in the struggle over land. Despite the chaotic appearance of land conflicts in Brazil, they follow a general pattern, with squatters and land owners acting strategically in choosing how much effort to supply in land disputes. This pattern allows us to model the interaction between squatters and land owners with a gametheoretic framework. The model includes the rules that motivate the antagonists. These rules, in turn, are determined by the government's land reform policy, the land reform agency (INCRA), and the actions of the courts. In this section we describe the model.

The objective of both the land owner and squatters is ownership of the land. We define violent conflict as personal injury or death and/or physical property damage in a land dispute. Conflicts arise from an invasion by squatters and efforts to evict by the owner. In these confrontations, squatters do not attempt to win the land by force. Rather their purpose is to attract the attention of INCRA and to convince it to expropriate the farm. Land owners, by contrast, want to evict the squatters quickly and avoid losing the farm through an expropriation.

Each side will supply effort so as to maximize the expected value of the land. For squatters this effort includes invasion, occupation of the farm, and resisting eviction. For land owners it includes threatening or intimidating squatters, hiring gunmen, and/or calling the police for an eviction. These efforts can be seen as inputs in land ownership disputes that ultimately can result in violent conflict. The model describes the optimal choice of inputs for each of the antagonists. We use the model to predict how shifts in key variables will lead squatters and owners to change their efforts and thereby affect the likelihood of violent conflict. 
In order to simplify, it is assumed that both the squatters and the land owner value owning the land at $L$. There are three possible outcomes of the conflict. ${ }^{42}$ One is that the squatters are evicted, receive nothing, and the land owner keeps the land. A second outcome is that the land is expropriated by INCRA in favor of the squatters, and the owner is compensated (usually) at below the market price of the land. In this case the owner receives $\gamma L$, where $0<\gamma$ $<1$. In the third outcome the squatters are not evicted, but neither is the land expropriated. The land owner tries to achieve the first outcome, and squatters try to achieve the second. The intermediary outcome arises when the conflict is not yet resolved, although land can be in this status for years. . It can occur for various reasons, including failure of INCRA to act or unresolved questions of beneficial use, when the owner also has not been able to evict the squatters. The value of the land to the squatters in this case is $\pi L$ and to the land owner it is $\delta L$, where $0<\pi<1$ and $0<\delta<1$. It is assumed that $\gamma<\delta<1$, so that for the land owner, the third stage is preferable to expropriation.

Table 1 presents the value of the land to each party under the various possible outcomes. With these land values in mind, both the squatters and the owners choose what efforts to take in their competition for control of the land.

Table 1

INCRA cannot address all land conflicts. The probability that INCRA expropriates a specific farm depends on three variables: the efforts taken by the squatters, $s$; the property rights of the land owner, $P$; and the commitment of the government to land reform, $G$. Squatter invasion, occupation, and eviction resistance, $s$, increase the likelihood of INCRA expropriation.

42 As we described earlier, there is the option for either side to walk away from a potential conflict. This would occur a), if the land owner was certain that INCRA would intervene on behalf of the squatters or if the land were of such low value that the land owner did not seek to enforce his claim; or b). if squatters were certain that INCRA would not intervene and that the land owner would be successful in enforcing his claim. 
The quality of the land owner's property rights depends on having title and placing the land in productive use (in the Amazon, clearing). The parameter $P$ can be thought of as a continuous variable. Not all of a farm will be cleared nor will all of it be necessarily titled. The stronger the property rights to the farm the lower will be the probability of an expropriation. The land owner's claim will be supported by both Civil and Constitutional law. Finally, the government's commitment to land reform also affects the probability of an expropriation. The government can accelerate or hinder land reform depending on the budgets and staffing provided INCRA and legislation that affects its mandate. We assume that the owner and squatters on a particular farm view the government's position on land reform as exogenous. Accordingly, the probability of expropriation of a given farm, $\theta$, is given by the function:

(1) $\theta(s, P, G)$ where $\theta_{s} \geq 0, \theta_{P} \leq 0$ and $\theta_{G} \geq 0$.

After an invasion squatters are subject to eviction by the land owner, and land owner efforts to intimidate or threaten squatters, $v$, makes a successful eviction more likely. The support of the courts, $K$, in upholding title and ordering evictions also assists the owner. The courts are assumed to be favorable to land owners, and the land owner must choose whether to rely solely on private gunmen, seek a court order for an eviction, or use some combination of these actions. The probability of the land owner's eviction being successful is given by the function:

(2) $\beta(v, K)$ where $\beta_{v} \geq 0$ and $\beta_{K} \geq 0$.

In their competition with land owners, squatters must determine how much effort to use to maximize their payoff in land value:

(3) $\operatorname{Max}_{\mathrm{s}}(1-\beta(\nu, K))[(1-\theta(s, P, G)) \pi L+\theta(s, P, G) L]-C^{S}(s) .^{43}$

${ }^{43}$ Assume that the efforts supplied by squatters and the land owner belong to the real line and that the land value functions for 
The objective function of squatters is made up of the expected land values in each possible outcome, weighted by the probability of that outcome, minus the cost of their efforts. The three possible payoffs are: a) $-C^{S}$, if squatters are evicted by the land owner; their investment in invasion and resistance brings no positive returns; b) $\pi L-C^{S}$, if squatters are not evicted, but the farm is not expropriated, and c) $L-C^{S}$, if the farm is expropriated. The first order condition for the maximization of the squatters' objective function is:

(4) $(1-\beta(v, K)) \theta_{s} L(1-\pi)=C_{s}^{s}$.

The term on the left is the marginal benefit from an additional unit of effort. $L(1-\pi)$ is the gain in squatters' value from an expropriation. This gain is multiplied by $\theta$ $s u b s$, the increase in probability of an expropriation resulting from a marginal unit of squatter effort, $s$. Since the expropriation can only occur if there has been no eviction, the value is weighted by the probability of no eviction by the land owner. The right side is the marginal cost of an additional unit of squatter effort. The first order condition (4) illustrates the trade-off faced by squatters. Although they have an incentive to engage in efforts to prompt INCRA to expropriate the farm, these efforts are costly. Accordingly, squatters chose an optimal amount of effort, $s$, that balances marginal costs and marginal benefits.

Similarly, land owners are faced with the problem of engaging in enough efforts to evict squatters and avoid expropriation. Each land owner must select the optimal amount of effort, $v$, that maximizes the expected value of the land, or (5) $\operatorname{Max}_{v} \beta(v, K) L+(1-\beta(v, K))[(1-\theta(s, P, G)) \delta L+\theta(s, P, G) \gamma L]-C^{F}(v)$.

Analogous to squatters, the objective function of the land owner is the expected value of the land in each possible outcome, weighted by the outcome's probability, minus the cost of

both parties are twice continuously differentiable in $\mathrm{s}$ and $\mathrm{v}$. Assume also that the land function is strictly concave in each party's 
offering $v$ units of effort. The expected values of the land owner's payoff under the three possibilities are: a) $L-C^{F}$, with a successful eviction, the land value with eviction less eviction costs; b) $\delta L-C^{F}$, with neither eviction nor expropriation, land value when squatters occupy but INCRA does not expropriate less the costs of eviction efforts; and c) $\gamma L-C^{F}$, with an expropriation, compensation received from INCRA after an expropriation less the land owner's costs.

The first order condition for maximization of the land owner's objective function is: (6) $\beta_{v}[\theta(s, P, G) L(\delta-\gamma)+L(1-\delta)]=C^{F}$.

This first order condition represents the trade off facing the land owner in determining how much effort to use in defending his farm against squatters. The term on the left is the marginal benefit to the land owner from offering an additional unit of effort. Because $\beta_{v}$ measures the marginal increase in the probability of a successful eviction of the squatters, the term in brackets measures the expected loss avoided by the owner from a marginal unit of effort. $L(1-\delta)$ represents the loss to the land owner from moving from an eviction to the case where there is neither eviction nor expropriation, and $\theta(s, P, G) L(\delta-\gamma)$ represents the expected loss from moving from the case of ncither eviction nor expropriation to an expropriation by INCRA. The term on the right measures the marginal cost of eviction effort.

The decisions by squatters and the land owner on how much effort to use are made strategically. Each of the antagonists understands the environment, the other side's valuation of the land under each outcome, and the probability functions. Thus, we would expect the joint solution of the optimization problems to be a Nash Equilibrium, where the optimal values $v^{*}$ and $s^{*}$ are such that equations (4) and (6) hold simultaneously. In such an equilibrium the key

supply of effort, so that the second order conditions for maximization are satisfied and the first order conditions are sufficient for 
probabilities are those for expropriation and eviction, $\theta\left(s^{*}, P, G\right)$ and $\beta\left(v^{*}, K\right)$ for any given level of $P, G$, and $K$--property rights security, the President's political pressure on INCRA to expropriate, and court rulings regarding squatter invasions. ${ }^{44}$

We use this framework to analyze empirically the determinants of land conflicts on the Brazilian Amazon frontier. We view conflicts for land as a static game, taking the variables $P, G$ and $K$ as exogenous. The model focuses on the behavior of the players at the time of the conflict and stresses the incentives provided by the rules that govern the land reform program. Once a conflict has begun, neither the land owner, nor squatters can clear forest or change the level of government or judicial support for property rights. Hence, a static model and estimation of the determinants of conflict as reflected in our data makes sense ${ }^{45}$ Comparative statics reveal how changes in parameters, such as the value of the land or the level of property rights security, affect the efforts of squatters and land owners in land disputes. The predictions from the comparative statics are outlined in Table 2. The formal derivation of the comparative statics results is presented in the appendix.

Table 2

The variables of interest to us are: the property rights of contested land, $P$; the value of land, $L$; and the costs of supplying effort, $C$. Changes in these variables can have both direct and

\footnotetext{
a Nash Equilibrium.

${ }^{44}$ In this paper we model the typical conflict setting the parameters such that the land owner would rather evict the squatters and keep the land than be expropriated and compensated by INCRA, that is, $0<\gamma<\delta<1$. As noted above, there are some cases where the compensation might be greater than the market value of the farm. In terms of the framework such cases can be modeled by setting $0<\delta<1<\gamma$. The equilibrium of the game with a sufficiently high $\gamma$ would have the land owner putting in no effort at eviction $\left(v^{*}=0\right.$ ) and the squatters having to put in less effort than in the original case ( $\operatorname{set} s^{*}$ to solve $\left.\theta_{s} L(1-\pi)=C_{s}^{S}\right)$. The probability of expropriation is higher in this case since both the squatters and the land owner are doing the best they can for an expropriation to materialize.

${ }^{45}$ In a game to attract (or avoid) INCRA intervention, which we do not attempt here because of an absence of data, the variables $G, K$ and $P$ could be considered as endogenous with both sides putting efforts into trying to affect the position of the government and the courts towards land reform and the level of property rights sccurity of a farm. Both landowners and squatters do in fact lobby the government at various levels and in many ways in order to change $G$ and $K$. Both parties might try to change $P$, through clearing prior to a conflict. As we have described in Section II, land owners and squatters have incentives to clear prior to a conflict and intervention by INCRA. For land owners, clearing reduces the likelihood of invasion and INCRA intervention by placing the property into productive use. For squatters, clearing improves their chances of receiving some compensation from
} 
strategic effects on squatters and land owners. ${ }^{46}$

From the equilibrium conditions it can be shown that the efforts of the land owner are strategic complements, whereas the efforts of the squatters are strategic substitutes. That is, the reaction curve (with land owner efforts on the horizontal axis and squatter efforts on the vertical axis) for land owners is positively sloped, whereas that for squatters is negatively sloped.

Accordingly, with the exception of changes in the costs to squatters, the direct and strategic effects identified from our model for squatters work at cross-purposes (see Table 2). Ultimately, the overall impact of changes in the exogenous variables on land owner and squatter effort is an empirical question.

Given our knowledge of conflicts, it seems reasonable to assume that for squatters the strategic effects are small in comparison to the direct effects. It makes sense for squatters to be relatively insensitive to land owner actions. Squatters select only farms with a high probability of expropriation. Once they have invaded, their tactic is to create a commotion and stick to it, despite land owner reaction, so as to attract INCRA. Land owners, however, must move quickly, and if squatters resist leaving, add more pressure to remove them before INCRA can intervene. With this assumption about squatter efforts we obtain predictable results from our comparative statics.

To illustrate the impact of shifts in key parameters, suppose that the property rights of land owners are less secure where larger percentages of land are in forest - a sign of a lack of beneficial use. For squatters in such regions, the direct effect is an increase in the propensity to invade because the likelihood of an expropriation is greater where beneficial use is not apparent.

INCRA should they be evicted.

" The direct and strategic effects can be understood in terms of the reaction curves that arise from the equilibrium conditions. The reaction curves show the level of effort that each side will choose given the level chosen by the other side. Changes in the exogenous variables lead to shifts in the reaction curve (direct effect), while changes in the amount of effort offered by one side 
For the land owner the direct effect of weaker property rights is an increase in private enforcement efforts. The greater likelihood of expropriation increases the expected net benefits of defensive actions. But the strategic effect for squatters is to reduce their resistance. We assume, however, that this reaction is comparatively small because the goal of squatters is to hold on and attract the attention of INCRA. This assumption allows us to predict more violent conflict in regions with weaker property rights.

Similarly, increases in land value should lead to more conflict between land owners and squatters. The direct effect for squatters of this change is to invade more, and given higher asset values, land owners also will take more efforts to evict squatters. Once again the strategic effect from our model is for squatters to resist less as a result of the perceived greater vigilance of land owners. As with decreases in property rights security, however, we expect these effects to be relatively small, and therefore we should observed more conflict in regions where land values are greater.

Shifts in the costs of invasion and eviction also will influence the behavior of the antagonists. If eviction costs for land owners fall, for example due to a favorable court ruling or to lower wages for private police, enforcement efforts following an invasion will increase. Accordingly, we expect to observe more conflicts as land owner eviction costs fall, provided the strategic effect on squatters is small.

Squatter costs will fall if it becomes easier to access INCRA to obtain an expropriation. As we have described, squatters on a particular farm must lobby INCRA to intervene. INCRA is not active in every municipio, and given high transportation costs on the frontier, contacting INCRA about the merits of a proposed expropriation can be a problem. Existing or new INCRA land reform settlement projects in the same municipio, however, signify lower-cost access to the 
agency. Squatter costs also could decline if INCRA received greater funding for expropriations. The knowledge that INCRA is more apt to intervene in a conflict reduces the costs of organizing squatters for an invasion. When squatter costs fall, the direct effect on squatters implies more invasions and, in this instance, the strategic effect from land owners also is to increase their efforts at eviction. This twin bolstering of incentives leads to clear theoretical prediction: more conflicts where the costs to squatters of invasion and resistance are lower.

This discussion identifies an interesting and unanticipated implication: More active expropriations by INCRA in response to violent conflicts and related political pressures for land reform, encourage even more conflicts. Hence, an activist land reform policy to reduce tension and land conflict will likely be counter productive.

The model developed in this section helps guide empirical testing of the determinants of land conflicts. An examination of the direct effects of the variable shifts as indicated in Table 2 , shows that as land values rise from road construction or other stimuli there will be more invasions and evictions. In contrast, as property rights become more secure, such as through more clearing, there will be fewer invasions and evictions. But as squatter costs fall, due to more active INCRA intervention for land reform through expropriation, squatters will invade more, and correspondingly, land owners will seek to evict them. When land owner costs fall, they too will devote more resources to eviction, and conflicts will escalate. We use these predictions in the empirical analysis of violent conflict over land in the Amazon.

\section{Analyzing the Determinants of Violent Conflict on the Amazon Frontier.}

The comparative statics provide testable implications regarding the impact on land conflicts from changes in the security of property rights, the value of land, and the costs of invasion and eviction to squatters and land owners. It is reasonable to infer that changes that lead 
to higher values of $s$ and $v$ will increase the number of conflicts in any given region. We do not have conflict-specific data, but we do have broader measures of conflicts and contributing variables that allow us to examine the underlying determinants of land-based violence in the Amazon. Our data include: conflicts per municipio from the Pastoral Land Commission; ${ }^{47}$ the incidence of squatting, forest clearing, farm size, land values, and number of farm establishments from the 1985 Brazilian Census; and number of settlement projects by município from INCRA. These data allow us to estimate the following equation:

(7). Conflicts $_{i}=\beta_{0}+\beta_{\text {I }}$ Settlements $_{i}+\beta_{2}$ Squatting $_{i}+\beta_{3}$ Clear $_{i}+\beta_{4}$ Concentration $_{i}+\beta_{5}$ Value $_{i}$ $+\beta_{6}$ Establishments $+e_{i}$.

Data are at the município kvel for the state of Pará. The dependent variable Conflicts is the total number of land conflicts from 1991 to 1994 as collected by the Pastoral Land Commission, which is a non-government organization that specializes in monitoring rural conflicts in Brazil. These are the most recent data on contemporary land conflicts available to us. We use cumulative data for this four-year period to obtain a better sense of the overall incidence of violent conflict in the Amazon.

We have emphasized the importance of the presence of the land reform agency, INCRA, as a factor in violent land conflict. As argued above, the likelihood of INCRA intervention in a specific conflict should reduce $X$, the cost to squatters of obtaining a farm's expropriation, and at the same time, encourage land owners to devote more efforts to protect their farms. ${ }^{48}$ In order to capture this effect we use the variable Settlements, the cumulative number of INCRA landreform settlements in a município from 1987 to $1990 .{ }^{49}$ INCRA is not active in every município,

\footnotetext{
${ }^{47}$ The Pastoral Land Commission defines conflicts as episodes in land reform where land owners attempt to evict squatters and they resist. Violence and property damage are generally associated with such resistance. Major cases of violent conflict are included in Pastoral Land Commission files.

${ }^{48} X$ is a parameter that represents any factor that makes it more or less costly for the antagonists to supply effort in land conflicts. Sec the appendix.

${ }^{49}$ These data were obtained from personal correspondence with INCRA, which provided a list of all settlement projects in Brazil
} 
and more settlement projects in a municipio indicate greater existing INCRA land-reform activity in that region. The presence of INCRA is a critical factor in reducing the costs to squatters of resisting eviction and of ultimately gaining the land. Our data place INCRA in particular municipios in varying degrees as of the initiation of the conflicts identified in our data set.

Special care must be taken in the estimation with regard to the variable Settlements. Beyond predicting that more settlements in a municipio by INCRA will lead to more conflicts, our model also incorporates the fact that an increase in violence leads to a higher probability of expropriation and consequently more settlement projects. Therefore estimation of equation (7) without attention to this simultaneity would lead to biased estimates. We take two steps in order to deal with this problem. The first is to use settlement data from 1987 to 1990 , a period before that used for the Conflict variable. Although the use of past INCRA settlements may remove most of the simultaneity, some effects may linger. There remains the possibility that some unobserved variable may be simultaneously correlated with both the number of conflicts and the number of past settlements in a municipio. In particular any municipio-specific characteristic that makes it prone to conflicts and settlements and which is not controlled for in equation (7) would be captured in the error term. Thus the error term would be correlated with the settlements variable and the estimates would be biased.

One way to account for this would be to use a panel data set with observations both across municipios and over time. With these data we could control for fixed effects either by adding municipio dummies or by taking first-differences. ${ }^{50}$ Unfortunately the data available to us at the municipio level are very limited. Although there are yearly data for Conflicts and

from 1987 to 1995 .

${ }^{\text {so }}$ For similar issues in estimation, see Lanjouw and Levy (1998). 
Settlements for the period 1987 to 1995 , annual data by municipio are not available for the other

variables. Accordingly, we take an alternative approach. We use a two-step procedure where

Settlements is estimated using the predetermined variables and instruments that capture

characteristics of the municipios that make it more or less costly for settlement projects to be

created. Because these variables are correlated with Settlements, but not with Conflicts, this

procedure gives us an estimated Settlements variable that contains only its exogenous

components. This estimated Settlements variable can be used in a second stage of the Conflict

equation leading to unbiased estimates. ${ }^{51}$

The data for the remaining independent variables are from the 1985 Brazilian census. ${ }^{52}$

The variables Squatting, Concentration, and Clear measure various aspects of the security of

land owner property rights, $P$, prior to invasion and subsequent conflict. Reduced property rights

security is predicted to result in more conflicts.

To see how each of these variables might affect property rights security, consider the

following: a). The squatting variable is the percentage of farms in a municipio operated by

squatters in 1985. This variable places squatters on site, occupying both private and government

land. Their presence in the region is a precondition for subsequent conflict with land owners,

and where squatters are more numerous, property rights to land will be less secure; b). Large

farms are more likely to have insecure property rights, both because they often have extensive

\footnotetext{
The instruments used are (i) a dummy variable for municipios under federal rather than state jurisdiction-INCRA is a federal agency; (ii) distance of the municipio to the state capital, Belem - to capture transportation costs and remoteness, and (iii) the total area of projects which received SUDAM credit in each municipio. In the Amazon region until the late 1980s all land within $100 \mathrm{~km}$ of a federal highway was placed under the jurisdiction of the federal land agency while the remaining land was left under the jurisdiction of the state land agency. After this jurisdiction returned to the state but INCRA remained in charge of land reform. The assumption here is that it is less costly for INCRA to create a settlement project in those municipios where it has had long-term jurisdiction. The rationale behind the SUDAM variable is similar. This was a federal credit line for large agricultural projects with the objective of leading to the occupation of the Amazon. In municipios with more S UD AM projects it should be less costly for INCRA to create settlement project. Distance from Belem will affect the costs of implementing settlement projects while, ceteris paribus, it should not be correlated with the number of conflicts. That is, although distance may affect conflicts, it does so through Settlements.

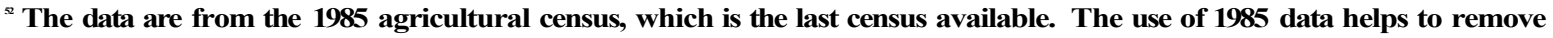
potential issues of simultaneity. Further, these variables change slowly over time.
} 
forested areas and because monitoring the boundaries of large farms is more costly. Further, large farms are the targets of land redistribution efforts. Our measure of the incidence of large farms in a municipio is a land-concentration variable, which is the sum of the area in farms equal to or larger than 5,000 hectares divided by the total area in farms in the municipio; and c). As defined by the Constitution, lack of beneficial use is an important justification for abridging property rights. In the Amazon, forest clearing is accepted evidence of beneficial use. More cleared areas in a municipio generally would increase property rights security. ${ }^{53}$ Our clearing variable is the mean farm area cleared in a municipio. ${ }^{54}$ Accordingly, municipios with more squatters, highly concentrated farm sizes, and more forest cover are likely to be characterized by violent conflict between land owners and squatters over land.

We use two different proxies for the variable Value. The first is the total value of farms divided by the number of farms in 1985 from the census. This measure is the average value of the farms in each municipio. ${ }^{55}$ By using the value of the land in 1985 and the number of conflicts from 1991-1994, we avoid the issue of simultaneity between conflicts and land values. Our alternative proxy for land value is the amount of rural credit provided per farm as measured in the census. Studies of the determinants of land prices in Brazil have found rural credit to be, by far, the variable with the most explanatory power. ${ }^{56}$ Further, there is no reason to believe that the allocation of rural credit is affected by conflicts, so this variable can be taken to be exogenous.

\footnotetext{
s. We recognize that both land owners and squatters have incentive to clear prior to a conflict in any particular invasion. Our clear data, however, are by municipio, and generally the more cleared a municipio the more likely its lands are in production with more secure property rights.

st Cleared farm area is calculated from the census by dividing the number of hectares of cleared agricultural land by the total amount of agricultural land in the municipio. The area cleared was defined as the sum of the land in permanent crops, annual crops, planted pasture, natural pasture, planted forest, and unused but usable land, as defined by the census.

ss This variable is measured in December 1985 cruzados and is in logs.

s Rezende (1982) and Brandao (1992). Our own regressions using land values and rural credit at state level for Brazil have confirmed these results. In this paper we cannot use rural credit as an instrument for land value because we do not have land value for the 1991-94 period at municipio level. The rural credit variable used here is total amount of rural credit received by farms in a municipio in 1993 divided by the number of farms in the municipio. These data are provided in annual reports by the Brazilian Central Bank. The data are in cruzeiros and are measured in logs.
} 
In municipios where the farms are more valuable, ceteris paribus, we expect to observe more conflicts.

The number of farm establishments is added as an explanatory variable to control for the fact that some municipios have more farms than do others, which may lead to a higher number of conflicts. This approach was adopted rather than estimating (7) using the number of conflicts per hectare or per farm because this scaling could affect the results in a spurious manner. Nevertheless, our results are similar if we use Conflicts and Settlements on a per farm basis.

In Table 3A we present descriptive statistics for the variables used in the estimation of equation (7). In Table 3B, we present the coefficients from our Tobit estimation. Column I shows the estimates using land values from the 1985 census and column II shows the estimates using rural credit as a proxy for Value. In both specifications the Settlements variable is the predicted value from the first stage as described above. The coefficient on INCRA Settlement is positive and significant at a 1 percent confidence level for both estimating equations. This result is consistent with the notion of a stronger INCRA presence in a municipio lowering squatters' costs of invading farms. The performance of the variable may also reflect a demonstration effect from past land reform settlements on the likelihood of future expropriations.

In both specifications all three variables capturing the security of property rights, Squatting, Clear and Concentration, have the predicted signs. Joint tests of the significance of all three property rights variables finds that for Estimation I, the variables are jointly significant at the 5 percent level $(p$-value $=0.014)$ and for Estimation II, the variables are jointly significant at the 1 percent level $(\mathrm{p}$-value $=0.008)$. Both estimations provide results consistent with the

\footnotetext{
"After 1985 a number of municipios were subdivided creating 22 new municipios, but we use the 83 municipios that existed in 1985 for our analysis aggregating the data from the subdivided municipios where necessary.

* We use Tobit estimation because only 29 of the 83 municipios had conflicts in the 1991-94 period. Performing the regressions with OLS did not alter the signs or significance of the estimates. The same is true when using a heteroskedastic-consistent covariance matrix (White, 1980).
} 
hypothesis that insecure property rights underlie land conflict in the Amazon. A high incidence of squatting in a municipio weakens property rights because it means that squatters are occupying land in the area. This situation leads to efforts by land owners to remove squatters from their lands. By contrast, those municipios characterized by high levels of forest clearing tended to have fewer conflicts. Cleared areas are considered in beneficial use and are less likely to be invaded. Finally, large farms are more likely to have insecure property rights than are small ones and hence are target for invasion and land redistribution. Owners of large farms are more apt to have their property invaded and to attempt eviction of the squatters.

The coefficients on both variables used to proxy Value are positive and significant at the 5 percent level of confidence. The positive relationship is consistent with the hypothesis that higher land values encourage invasions and evictions. The coefficient for the number of farms in each municipio is negative, but not significant in either equation.

To better appreciate the impact of changes in the independent variables on the incidence of land-related conflicts, we calculate the impact of a one-half standard deviation shift in the independent variables on the expected number of conflicts. ${ }^{60} \mathrm{With}$ the independent variables at their mean levels there would be an expected 1.12 conflicts in each municipio during the period of 1991-1994. A one-half standard deviation increase in the number of INCRA land-reform settlement projects (Settlements) in the period of 1987 to 1990 would lead, instead, to 1.64 conflicts in each municipio. The corresponding numbers of expected conflicts, given a one-half standard deviation increase in the other independent variables are: Squatting 1.41, Clear 0.93, Concentration 1.33, Value 1.55, and Establishments 1.06. The largest impact is Settlements, our

\footnotetext{
* Joint tests of the significance of all three property rights variables finds that for Estimation 1, the variables are jointly significant at the 5 percent level $(p$-value $=0.011$ ) and for Estimation 2, the variables are jointly significant at the 1 percent level (p-value $=$ 0.0048).

* The remainder of this section interprets only the results in column I using land value form the 1985 agricultural census.
} 
measure of the impact of INCRA on the costs to squatters of invading and seeking expropriation of the farm. The magnitude of this effect is followed closely by the impact of Value.

To further explore the implications of our estimation we calculate the marginal effects of each independent variable on the number of conflicts and decompose that impact into two separate effects. These effects can be distinguished because our sample has both municipios with no conflicts (municipios at the limit) and municipios that experienced some conflicts (municipios above the limit). The first column in Table 4 shows the total marginal effect on conflicts of a change in each independent variable. ${ }^{61}$ In the second and third columns of the table this total effect is separated into: (i) the change in the number of conflicts in municipios above the limit, weighted by the probability of being above the limit; and (ii) the change in the probability of being above the limit, weighted by the expected number of conflicts the municipio would have had if it were above the limit. This decomposition allows us to calculate what fraction of the total effect is due to each of (i) and (ii), given our sample. That is, we can separate the impact of the independent variables on conflicts within municipios that already had conflicts and on the probability of conflicts within municipios that previously had none.

We find that 28 percent of the total change in conflicts resulting from a change in the independent variables was generated by marginal changes in the number of conflicts, while 72 percent of the total change in conflicts was generated by the probability of there being a conflict at all. For example, an additional INCRA settlement project during the period of 1987 to 1990 would lead to an expected 1.33 more conflicts over land. Of this total impact, an increase of 0.37 conflicts was due to more conflicts in those municipios that already had them, whereas an increase of 0.96 was due to the increased likelihood of having a conflict in those municipios that

\footnotetext{
${ }^{61}$ The coefficients in the first column of Table 4 are the correct values of the marginal effects of each independent variable. They are calculated as ( 3 times $F(z)$, see notes on Table 4.
} 
previously had had none. The effects of the other independent variables can be analyzed analogously and are shown in Table 4.

These results have important policy implications for they suggest that the Brazilian government should concentrate as much effort in preventing any conflicts from arising as it does in reducing the number of conflicts in those municipios where some conflicts have already occurred. Currently, violent conflict is concentrated in particular areas. Yet, the empirical results presented here suggest that shifts in the independent variables, particularly INCRA land-reform presence, may encourage violent conflicts to occur in other areas that previously had not had them. Hence, whereas political pressures lead INCRA to expropriate invaded farms so as to reduce existing tensions in competition over land, the unanticipated result is to promote the spread of violent conflict to other municipios. Land-reform expropriations under current policies may prompt even more invasions, evictions, land-based violence, and calls for further expropriations. If correct, breaking this cycle would seem to be essential for halting the transmission of violent conflict on the Amazon frontier.

\section{Conclusion.}

Violent conflicts over land in the Amazon have received considerable international attention. These conflicts have the potential to reduce welfare through the dissipation of land rents and through the deaths of the parties involved. Yet, violence is not a uniform characteristic of the Brazilian Amazon. It occurs in specific locations. Determining the characteristics of those regions where violent conflict has taken place provides policy implications for reducing the potential for violence. In this paper, we have analyzed land conflicts in the state of Para between 1991 and 1994 with data from the census, INCRA, and the Pastoral Land Commission.

The principal antagonists are large land owners and squatters. The basis for their disputes

\footnotetext{
${ }^{62}$ We follow the technique developed by McDonald and Moffit (1980).
} 
are conflicting aspects of Brazilian law. Title holders have rights through statutory law for government enforcement of their property rights, whereas squatters have rights for land redistribution (land reform) under the Constitution, most recently reaffirmed in 1988. Land must be placed in beneficial use or it is subject to expropriation and reassignment to squatters.

Given this institutional setting, the factors that most contribute statistically to conflicts include the number of past INCRA settlement projects in a municipio and increases in land values. The number of settlement projects is a proxy for the land-reform efforts of INCRA. Anticipation of INCRA expropriations appears to have encouraged invasions by squatters and accelerated attempts by land owners at evictions. INCRA is charged with land reform by the Brazilian President and Congress, and both the agency and the President are embarrassed politically by highly-visible incidents of violent conflict over land. Ironically, the greater policy emphasis on land reform through the use of expropriations and settlements appears to have the unanticipated impact of increasing land conflicts.

The extent of squatting, land concentration, and forest clearing also play a role in land conflict. Higher levels of squatting in municipio and more land inequality lead to more conflicts whereas, forest clearing reduces the potential for land disputes. This last finding suggests that land owners particularly, but also squatters as well, have incentives to clear in order to firm their claims to Amazon lands prior to a conflict. Regarding forested lands as "unused" lands and therefore subject to invasion and redistribution, raises problems for efforts to set aside large tracts of Amazon rainforest.

The inconsistent practices of assigning and enforcing title through evictions in civil law, but allowing for invasions and expropriation, if the property is not placed in beneficial use under constitutional law, create a volatile environment for violent conflict over land. The problem 
extends beyond Brazil to elsewhere in Latin America, where there is tension between the efficiency gains from secure property rights and distributional objectives of land reform. As illustrated in the Brazilian Amazon, the institutional environment that has emerged results in confusion, conflicting incentives, and welfare losses. Although we do not have the data to measure the losses in welfare from injuries, deaths, property damage, accelerated deforestation, and lower land values due to uncertain property rights, there appear to be important gains from the redesign of land-reform policies that halt the damaging cycle of invasion and eviction. With the entrenched constituencies involved and the intensity of their competing demands, adoption of a new model of land reform presents a formidable political challenge.

Responding to the often-competing objectives of secure property rights and land redistribution requires careful maneuvering by politicians and bureaucrats under the best of conditions. Given the existing complex and volatile situation, it is unclear how effective the government will be. Indeed, the Minister of Land Reform in July 1996 called for revised popular expectations as to what could be realistically accomplished by the government for land reform. ${ }^{43}$ The situation in Brazil underscores the importance of politics and competing objectives in determining how well governments can create and maintain the necessary institutions for sustained economic growth and optimal resource use. 


\section{Appendix}

In this appendix we derive the predictions of the comparative static results described in Table 2. To simplify the derivation of testable hypotheses, a few assumptions are made. ${ }^{1}$ We assume that $\pi=0, \delta=1$, and $\gamma=0$; that is, the squatters' valuation of the land, if there is neither eviction nor expropriation, is zero and the land owner values the land at its full value, L; additionally, there is no compensation to the land owner if the land is expropriated. With these simplifications equations (4) and (6), the squatters' and land owner's first order conditions, respectively become:

(A2) $\beta_{v}(v, K) \theta(s, P, G) L-C_{v(v)}^{F}(v)$.

In a Nash Equilibrium equations (A1) and (A2) hold simultaneously, allowing us to differentiate both equations with respect to an exogenous variable or a parameter and to solve the resulting system to determine the impact on squatter and land owner efforts. Accordingly, we analyze the impact of a). changes in the level of property rights security, $P$; b). changes in land value, $L$; and c). changes in the cost functions, $C^{S}$ and $C^{F}$.

Differentiating equations (A1) and (A2) with respect to $P$ and rearranging, yields a set of simultaneous equations which we solve to obtain the following expressions for the effect of a change in the level of property rights security on the amount of effort offered by the squatters and by the land owner: ${ }^{2}$

$$
\begin{aligned}
& \partial v / \partial P=\left\{\left[(1-\hat{a}) \grave{e}_{s s} L-C_{s s}^{S}\right]\left[-\hat{a}_{v} \grave{e}_{P} L\right]-\left[\hat{a}_{v} \grave{a} \delta_{s} L\right]\left[-(1-\hat{a}) \grave{e}_{s} L\right]\right\} / \mid \text { det } \mid \\
& \partial s / \partial P=\left\{\left[-(1-\hat{a}) \grave{e}_{s P} L\right]\left[\hat{a}_{w} \grave{e} L-C^{F}{ }_{w}\right]-\left[-\hat{a}_{v} \grave{e}_{P} 24 L\right]\left[-\hat{a}_{v} \grave{e}_{s} L\right]\right\} / \mid \text { det } \mid
\end{aligned}
$$

\footnotetext{
1 None of these simplifications alters the basic results obtained below.

${ }^{2}$ From here on we drop the arguments of $\beta$ and $\theta$ to simplify the presentation.
} 
where $\mid$ det $/$ is the determinant of the following matrix: ${ }^{3}$

$$
\left|\begin{array}{cc}
(1-\beta) \theta_{s s} L-C_{s s}^{S} & -\beta_{v} \theta_{s} L \\
\beta_{v} \theta_{s} L & \beta_{v} \theta L-C_{v v}^{F}
\end{array}\right|
$$

By definition $\theta_{P} \leq 0$ and $\theta_{s P} \leq 0$; that is, an increase in the level of the land owner's property rights security decreases the probability of INCRA expropriation. The term $\theta_{P}$ is the effect of the security of tenure on INCRA's probability of expropriating and the term $\theta_{s P}$ is the effect of INCRA becoming less responsive to squatter efforts when tenure is more secure (such as, if the farm is cleared of forest). Accordingly, $\partial \mathrm{v} / \partial \mathbf{P}$ can be shown to be unambiguously negative. To understand the logic, examine the land owner's first order condition (A2). The term $\beta_{v} \theta L$ is the marginal benefit to the land owner from an additional unit of effort, $v$. By increasing $v$ the probability of an eviction is increased by $\beta_{v}$, reducing the probability of the potential loss from an expropriation, $\theta L$. If the land owner's tenure security is increased, however, the likelihood of an expropriation, $\theta$, will be smaller and the potential loss will be reduced. This means that the pay-off from a higher $v$ is lowered, and the land owner will supply less effort.

By contrast, the sign of $\partial s / \partial P$ depends upon two effects, which can be seen in the squatters' first order condition (A1). The term $(l-\beta)_{s} L$ is the marginal benefit to the squatter of offering an additional unit of effort. The direct effect of an increase in $P$ is to reduce the marginal benefit, since $\theta_{s P}$ is negative, leading squatters to use less effort. The strategic effect occurs because the land owner will offer less enforcement effort given an increase in $P$, so that

\footnotetext{
${ }^{3}$ In order to interpret the comparative static results it is necessary to determine the signs of each term in the above equations. It will be assumed that $\beta_{\nu v}$ and $\theta_{s s}$, the second derivatives of the probability functions, are all negative. This assumption seems reasonable sincc probabilities are bounded between zero and one, so that it should be expected that as effort increases the functions would tend asymptotically to one. Additionally the second derivatives of the cost functions, $C_{s s}^{S}$ and $C^{F}$, are reasonably assumed to be positive. Given these considerations, and that the terms on the main diagonal are negative due to the second order condition for maximization, / det/is seen to be positive.
} 
the term $(1-\beta)$, which is the probability of no eviction, will be larger. This implies a larger marginal benefit to squatters from more effort, which leads squatters to choose a higher level of $s$. If the strategic effect is smaller than the direct effect, as we assume, the sign of $\partial s / \partial P$ will be negative. In this case an increase in $P$ will lead to more efforts from both the squatters and the land owner, therefore implying more conflicts.

To determine the effect of an increase in land value on land owner and squatter efforts, we differentiate equations (A1) and (A2) with respect to $L$ and obtain the following expressions: (A5) $\partial v / \partial L=\left\{\left[(1-\hat{a}) \grave{e}_{s s} L-C r S_{s s}\right]\left[-\hat{a}_{v} \dot{e}\right]-\left[\hat{a}_{v} \grave{e}_{s} L\right]\left[-(1-\hat{a}) \dot{e}_{s}\right]\right\} /|\operatorname{det}|$ (A6) $\partial s / \partial L=\left\{\left[-(1-\hat{a}) \dot{e}_{s}\right]\left[\hat{a}_{v v} \dot{e} L-C_{v v}^{F}\right]-\left[-\hat{a}_{v} \grave{e}\right]\left[-\hat{a}_{v} \dot{e}_{s} L\right]\right\} /|\operatorname{det}|$.

In equation (A5) the first and second terms in brackets are negative; the third term is positive; and the fourth term is negative. Thus an increase in the value of land unambiguously leads to an increase in the amount of eviction effort offered by the land owner. This effect is demonstrated in the land owner's first order condition (A2), where an increase in land value, $L$, increases the benefit of resorting to an additional unit of effort, $v$.

In equation (A6) the sign of $\partial s / \partial L$ depends on the strength of two different effects. An increase in land value, $L$, raises the marginal benefit of invasion effort in the squatter's first order condition, $(1-\beta) \theta_{s} L$, leading squatters to be more aggressive. However, once again there is a strategic effect. The increase in land value also leads to a greater amount of land owner effort and thus a lower value for $(1-\beta)$, which decreases the marginal benefit of squatter effort and prompts a lower value of $s$. We assume that the positive direct effect of the increase in land value is stronger than the negative effect of a more determined land owner, so that the increase in land value will lead to more invasion effort by squatters. Thus both land owner and squatter will offer more effort and we can expect an increase in conflicts. 
To analyze the impact on violent conflict from a parametric shift in the squatters' and land owner's cost functions, we assume that the functions contain parameters $X$ and $Y$, respectively. These parameters can represent any factor that makes it more or less costly for the antagonists to supply effort. The cost functions are $C^{S}(s, X)$ for squatters and $C^{F}(v, Y)$ for the land owner, such that $C_{X}^{S} \geq 0, C^{S}{ }_{S X} \geq 0, C_{Y}^{F} \geq 0$ and $C^{F}{ }_{V Y} \geq 0$. The effects of a change in squatter costs, $X$, on squatter and land owner efforts are:

(A7) $\partial s / \partial X=\left\{\left[C_{s t}^{S}\right]\left[\hat{a}_{v v} \dot{e} L-C_{v v}^{F}\right]\right\} /|\operatorname{det}|$

(A8) $\partial v / \partial X=\left\{-\left[\hat{a}_{v} \dot{e}_{s} L\right]\left[C_{s X}^{S}\right]\right\} /|\operatorname{det}|$.

Both of these expressions are negative. When it becomes more expensive for squatters to supply invasion effort they supply less. Given that squatters are less aggressive, the land owner's marginal benefit of effort in (A2), $\beta_{v} \theta L$, is smaller, and accordingly, less $v$ is chosen. Potential INCRA intervention should reduce $X$, the cost to squatters of effort. That is, the possibility of an INCRA expropriation makes it easier for squatters to organize, invade a farm, and resist the land owner's eviction. Moreover, under those circumstances, land owners have an incentive to supply more eviction effort to counter the actions of squatters in order to secure their land claims.

The effects of a change in land owner costs, $Y$, are:

(A9) $\partial s / \partial Y=\left\{-\left[C^{F}{ }_{v \gamma}\right]\left[-\hat{a}_{v} \grave{e}_{s} L\right]\right\} / \mid$ det $\mid$

(A10) $\partial v / \partial Y=\left\{\left[(l-\hat{a}) \grave{e}_{s s} L-C_{s s}^{S}\right]\left[C_{v y}^{F}\right]\right\} /|\operatorname{det}|$

Expression (A10), is negative; as effort becomes more expensive, the land owner supplies less of it. Expression (A9) by contrast is positive. An increase in $Y$ reduces the level of land owner effort and raises the squatters' marginal benefit of effort in (A1). However, if as assumed, 
this strategic effect of the change in the land owner's cost is sufficiently small, a reduction in $Y$ will lead to an increase in conflicts.

We do not show the result of changes in $K$ or $G$, the support of the courts in upholding title or the commitment of the government to land reform, because we do not have data to test hypotheses concerning these variables. It can be shown, however, that assuming a relatively inelastic squatters' reaction curve and that $\theta_{s_{G}} \geq 0$ and $\beta_{v K} \geq 0$, an increase in $G$ and $\mathrm{K}$ leads to an increase in both $s$ and $v$. In general, the courts are always supportive of land owner property rights and support evictions. 
Table 1

Land Value Under Different Outcomes

\begin{tabular}{|c|c|c|}
\hline Outcome & Land Value to Squatter & Land Value to Land Owner \\
\hline $\begin{array}{c}\text { Farmer Successfully Evicts } \\
\text { Squatters }\end{array}$ & 0 & $L$ \\
\hline $\begin{array}{c}\text { Squatters Successfully Obtain } \\
\text { Expropriation }\end{array}$ & $L$ & $\gamma L$ \\
\hline Neither Eviction Nor Expropriation & $\pi L$ & $\delta L$ \\
\hline
\end{tabular}

Table 2

Determinants of Violent Conflict

\begin{tabular}{|c|c|c|c|c|}
\hline \multirow{2}{*}{ Parameter } & \multicolumn{2}{|c|}{$\begin{array}{c}\text { Effect on Efforts by the Land } \\
\text { Owner }\end{array}$} & \multicolumn{2}{c|}{ Effect on Efforts by the Squatter } \\
\cline { 2 - 5 } & Direct Effect & $\begin{array}{c}\text { Strategic } \\
\text { Effect }\end{array}$ & Direct Effect & $\begin{array}{c}\text { Strategic } \\
\text { Effect }\end{array}$ \\
\hline $\begin{array}{c}\text { Property Rights } \\
\boldsymbol{P}\end{array}$ & - & - & - & + \\
\hline $\begin{array}{c}\text { Land Value } \\
\boldsymbol{L}\end{array}$ & + & + & + & - \\
\hline $\begin{array}{c}\text { Squatter's Cost } \\
\boldsymbol{X}\end{array}$ & & - & - & \\
\hline $\begin{array}{c}\text { Land Owner's Cost } \\
\boldsymbol{Y}\end{array}$ & - & & & + \\
\hline
\end{tabular}


Table 3A

Descriptive Statistics

\begin{tabular}{|l|c|c|c|c|}
\hline & Mean & $\begin{array}{c}\text { Standard } \\
\text { Deviation }\end{array}$ & Minimum & Maximum \\
\hline Conflicts & 1.783 & 3.960 & 0.00 & 25.00 \\
\hline Squatting & 0.153 & 0.158 & 0.00 & 0.79 \\
\hline Clear & 0.366 & 0.173 & 0.02 & 0.81 \\
\hline Concentration & 0.168 & 0.226 & 0.00 & 0.94 \\
\hline Settlements & 0.386 & 1.387 & 0.00 & 9.00 \\
\hline Land Value & 4.221 & 1.111 & 2.240 & 6.940 \\
\hline Credit & 0.150 & 3.347 & -4.610 & 5.750 \\
\hline Establishments & 3050.80 & 2897.50 & 128.00 & $15,156.00$ \\
\hline
\end{tabular}

Definitions and Sources: See text.

Table 3B

Regression Results: Land Conflicts

\begin{tabular}{lcc}
\hline Specification & $\begin{array}{c}\text { I } \\
\text { Estimated } \\
\text { Settlements }\end{array}$ & $\begin{array}{c}\text { Il } \\
\text { Estimated } \\
\text { Settlements } \\
\text { and Credit }\end{array}$ \\
\hline Constant & $-11.16^{* *}$ & -4.28 \\
Settlements & $(-2.46)$ & $(-1.54)$ \\
Squatting & $2.90^{* *}$ & $2.48^{* *}$ \\
Clear & $(3.27)$ & $(2.22)$ \\
Concentration & $9.66^{*}$ & 8.17 \\
& $(1.95)$ & $(1.45)$ \\
Land Value & -6.92 & -6.27 \\
& $(-1.45)$ & $(-1.20)$ \\
Credit & $6.01^{*}$ & $11.24^{* * *}$ \\
& $(1.91)$ & $(3.09)$ \\
Establishments & $2.01^{* *}$ & \\
& $(2.23)$ & $0.67^{* *}$ \\
\hline Sigma & & $(2.56)$ \\
Wald Chi-Square Stat. & $51.36^{* * *}$ & -0.0001 \\
$\left(\chi_{6}^{2} 1_{1 \%}=16.81\right)$ & & $(-0.321)$ \\
\hline
\end{tabular}

Notes: Tobit estimation; t-statistics in parenthesis; $\mathrm{N}=83$

Level of significance (Wald Chi-square statistic): $1 \% * * *, 5 \% * *, 10 \% *$

The coefficients presented are the regression (non-normalized) coefficients. 
Table 4

Marginal Effects of Independent Variables on Conflicts

\begin{tabular}{|c|c|c|c|}
\hline Variable & $\begin{array}{c}\text { Total effect on } \\
\text { conflicts } \\
\left(d \mathrm{Ey} / d \mathrm{x}_{\mathrm{j}}\right)\end{array}$ & $\begin{array}{c}\text { Effect above the limit } \\
\mathrm{F}(\mathrm{z})\left(d \mathrm{Ey}^{*} / d \mathrm{x}_{\mathrm{j}}\right)\end{array}$ & $\begin{array}{c}\text { Effect on probability } \\
\left(\mathrm{Ey} *\left(d \mathrm{~F}(\mathrm{z}) / d \mathrm{x}_{\mathrm{j}}\right)\right)\end{array}$ \\
\hline Settlements & 0.999 & 0.284 & 0.715 \\
\hline Squatting & 3.324 & 0.943 & 2.381 \\
\hline Clear & -2.382 & -0.676 & -1.706 \\
\hline Concentration & 2.068 & 0.587 & 1.481 \\
\hline Land Value & 0.690 & 0.196 & 0.494 \\
\hline Establishments & -0.00004 & -0.00001 & -0.00003 \\
\hline
\end{tabular}

The table shows the result of the decomposition suggested in McDonald and Moffit (1980) on the results in column I in Table 3B, where $\left.\left(d \mathrm{Ey} / d \mathrm{x}_{\mathrm{j}}\right)=\left(\mathrm{F}(\mathrm{z}) d \mathrm{Ey}^{*} / d \mathrm{x}_{\mathrm{j}}\right)\right)+\left(\mathrm{Ey}^{*}\left(d \mathrm{~F}(\mathrm{z}) / d \mathrm{x}_{\mathrm{j}}\right)\right)$. Ey is the expected number of conflicts for all observations and Ey* is the expected value of conflicts for observations where there were any conflicts. $F(z)$ is the cumulative density function and $z$ an index equal to $X \beta / \sigma$. The value of $\sigma$, the normalizing parameter, is 4.887 . The fraction of mean total response due to response above the limit is 0.28 . 